\title{
Àlvaro Siza and the Fragmented City
}

\author{
By Carlos Machado*
}

In Alvaro Siza's work, between 1970 and 1980, the presence of the ruin results from his quest for a methodology that allows the inclusion of the city's past and its remains as an important starting point to embrace reality in its broadest sense. Ruins found in the place were preserved as important references for the project to come. Proposed new forms were sometimes fragmented and the broken surfaces were used to relate or to bring together different aspects of reality. However, there were also invented ruins, intended as such and built as mediators between the pre-existing buildings and the new ones. Alvar Aalto and Fernando Távora, both important in Siza's upbringing, had previously addressed the same theme - the Muuratsalo experimental house by Aalto and the Quinta da Conceição Park in Matosinhos by Távora are good examples of the use of the fragmented form. They paved the way to Siza's practice as a mature architect. For Siza, there is no difference between architecture and urbanism. Aldo Rossi advocated the same idea, speaking of the transformation of monuments into city spaces and of the city distinguished by its various parts, studied and designed as such. The transformation of urban monuments over time and the conviction that the understanding of the city must come from the multiple inter-relations of its different singularities, also explains Siza's fascination with the fragment and the collage, thus allowing to interpret his sketches where broken angels and architectural fragments come together and interact.

Keywords: Álvaro Siza, City, Fragment, Ruin

\section{Fernando Távora and Alvar Aalto}

In Álvaro Siza's work, as from 1970, the fragment and the ruin come as the result from the quest for a methodology of the urban project that might include the city's past and its remains as a starting point to embrace reality in its most comprehensive dimension. Ruins found in place were preserved as important references for the project to develop. New forms were sometimes fragmented, using broken surfaces as a way of bringing different aspects of the same reality together. He also proposed invented ruins built as mediators between the pre-existing buildings and the new ones.

Alvar Aalto and Fernando Távora, important names in Siza's upbringing, had already addressed the same theme - the Muuratsalo experimental house by Aalto and the Quinta da Conceição in Matosinhos by Távora are good examples of it. They remained important influences not only in his years of learning but also throughout his later practice.

In the Quinta da Conceição (1956-60) by Fernando Távora, an urban park in Matosinhos, near the harbor of Leixões, ruins of an old convent are the

*PhD Architect, Researcher at FAUP Architecture and Urbanism Study Center (CEAU)/Group: Architecture: Theory, Project and History, Portugal. 
starting point for the organization of the farm as a public leisure area. Old and new complement each other. The remains of the convent are incorporated as part of a whole that was necessary to reorganize and complete, without the need to rebuild it as it was.

Inside the larger pond of the three-square ponds fountain in the south sector of the park is a baroque statue with its pedestal. The red niche, placed in order to culminate one of the box tree walks, which frames the remains of the old cloister, recomposing the space of the galleries, lodges another sculpture, this one incomplete or mutilated. There is also a small-rebuilt door aligned with the north entrance and, farther south, a portal in Manueline-style, which Távora sets in a concrete wall, turned west as the beginning of a walk at the lower border of the park.

It is a reconversion open to the past, where the will to render explicit the insertion of the new work into a collective, long-duration process becomes very clear. It recognizes the need to work from the existing, finding a way of integrating it into the project. Távora is always more interested in what unites architecture along time than in the specific characteristics of each period. This is what Quinta da Conceição reveals and it will remain as a recurrent theme in Siza's work.

The fragment arises in Alvar Aalto's work using the broken surface and the partition of the bodies into independent though aggregated units. In the house in Muuratsalo, Finland (1952-53), the various bodies are placed on the ground as fragments evoking a ruined building. In the Enso-Gutzeit building, Helsinki (1959-62), the parallelepiped volume is excavated on the side facing the Byzantine Cathedral, as if it was the result of a collapse in order to open a passage to illuminate the inner court, whereas in the Nordic Bank Union Building, Helsinki (1960-65) the broken surface of the façade allows the interlinking of a seven-storey building with the adjoining three-storey house. In this and other Aalto's works it is possible to find a way of interlinking or connecting different things without a single moment of change, thus dissolving into a successive transition.

This is a practice Siza will use in a number of his works. One of the beams in the house of Manuel Magalhães, Porto (1967-70) disappears or flows, with an undulating motion, into the ceiling of one of the rooms (someone described it, I wonder if the author himself, as a spring which disappears in the desert), a subtle and recurrent way to draw, introducing suspension, without necessarily choosing a sole moment of passage, but rather a prolonged transition. These episodes, although in some cases single or detailed ones, participate in a more general idea, the careful projecting of the moments of transition. It is as if everything had to be united by a rather tenuous string, which organizes an uninterrupted spatial sequence running along the whole work and projects itself to the outside, to the garden, to the city and to nature.

In the same way, but at a different scale, two houses at the northern end of the Caxinas housing estate, Vila do Conde (1970-72), share one of the sides of a small square, which limits the sea-front of the row houses foreseen as the union of both nuclei Siza built. In this case, the broken wall refers to the idea of 
ruin (or fragment) used as a transient motive to make the above mentioned side façades of both houses come closer to each other. At the southern end, the multifamily building built upon the remains of an existing construction, a coffee shop, underlines the compatibility of architectures along the time.

\section{The Invented Ruin}

In Alcino Cardoso's house in Moledo (1971-73) the idea of an invented ruin first arises in the sketches of the project and in the accompanying text. This house is usually interpreted as a juxtaposition between the existing and the new work based on opposition and difference (interpretation legitimated by the author's words when he says that 'the extant and the new elements establish a clear contrast and interpenetrate themselves violently'). (Siza 1979, 72)

In our opinion, the opposition is mainly planimetric. The same description also refers that 'there was an attempt to recover the character of the [existing] buildings and of the landscape' (Siza 1979, 72). This recovery both includes the existing and the new. We think that this work can be interpreted as a way of creating compatibility so to say by sympathy among the existing agricultural buildings and the projected enlargement. A non-mimetic sympathy, but clearly formulated in many of its aspects; the covering of the new body replicates the height of the existing harbor, kept as vegetal brise-soleil. The framework is based on a traditional pattern - the sash-window - and encloses the three sides of the new body. This kind of framework is common in countless cities in the north of Portugal (the interior of the blocks are often characterized by large multi-colored glass panes formed by the succession of closed verandas).

In the Alcino Cardoso's house, the character of the buildings and of the landscape arises as the primary motive of the project. Moreover, it is exactly because of this that the disturbing and fascinating episode of the swimming pool makes sense, situated at a lower level near the southern limit of the property.

The later projected swimming pool, was designed as an invented ruin from the memory of a number of things belonging either to the landscape of Minho or to other landscapes. It is oriented according to the course of the sun and intends to relate itself with everything that surrounds it, "new and old" as if it was an intermediary or an (im)possible synthesis. (Siza 1979, 72)

The ruin is present to set an (im)possible synthesis. The whole work is related to that open problem which was not sought for, but that was encountered along the project and its construction.

In the Campo Alegre art gallery, Porto (1973-74), the unfolding of planes, a characteristic of cubism, allows the representation of a fragmented world. Considering the multiplicity of scales of the stairs to the basement, it also evokes the restlessness caused by an immeasurable space (the Piranesi prisons 
arise to memory) which is multiple and irreducible to the objective laws of perspective.

In the Beires house, Póvoa do Varzim (1973-76) the façade was designed to look like a fully glazed marquise, so that those traditional pans de verre above referred appeared among the fragments or the remains of a ruined house. It is a singular and unrepeatable operation, almost uncommon or extravagant, but that heralds future developments that will confirm the correctness of that response.

\section{The Remains of the Past}

In the renewal of the Senhora das Dores area, S. Victor Resident's Association, Porto (1974-77), many of the previously referred themes come together. Starting from the existing remains of ancient buildings, such as in the Quinta da Conceição park, this project may also be the one where the idea of the non distinction between architecture and urbanism ${ }^{1}$ becomes more explicit and is utterly developed. (Siza, 1996 in Machabert, Beaudoin, 2008: 163-174)

Superimposed to the ruined walls which circumscribed the old ilhas (dispossessed and demolished for a parking lot by the municipal administration), a long row of houses with north-south orientation and parallel to the S. Dionísio's street opens a second front turned to the interior of the block that Siza intends to render permeable and open to the existing city. (Ilhas (in Portuguese), or islands (in English), is the name used in Porto for speculative occupation of inner residential areas for jerry-building for migrant population that arrived into the city since the industrial revolution. They are organized in single or double rows and have one unique façade).

The S. Dionísio's and Senhora das Dores's streets play a central role in this strategy - particularly the second one, a cleft halving the area, a street/alley which is also an expansion joint allowing the north-south crossing as well as the access to the interior of the block.

Siza also endeavors to restore old relationships of proximity and neighborhood he considers must be preserved.

The other face of the stimulating communitarian life of the ilha [island] is - just like the word suggests - the separation of the population into small isolated units. For this reason, the population as a whole repudiates the image of the ilha. But to repudiate that image and what it implies in terms of separation and misery does not necessarily mean to refuse the system of topographic adaptation with everything it has of positive for that communitarian life. (Siza 1976b, 101)

\footnotetext{
${ }^{1}$ Title of one of the interviews led and edited by Dominique Machabert and Laurent Beaudoin in Álvaro Siza, une question de mesure.
} 
Thus, the island frees itself from its usual aspects, particularly the unacceptable ones - lack of sewage, insufficient areas, isolation and occultation -, and in a broader sense it gets a new meaning: the maintenance of communitarian forms aggregated by strong formal and spatial relations, although opened and permeable to the whole city so that the city may look upon itself, in a formal, spatial and civil sense, and grasp the different local communities that form part of its whole.

The tradition of ancient inner occupations of the medieval city is thus recovered. Lewis Mumford refers the idea of island as being connatural to the formation of the medieval city. The ilhas of Porto may refer, including through their name, to an unsuspected historical dimension. And, even though this does not justify these interventions, it allows us to consider them under another more comprehensive and promising point of view - which opens ample perspectives to the Siza's proposition uttered in 1976, namely to consider the proletarian island as the basic element of the urban tissue (Siza, 1976a: 8093).

The wall, with its outside moat both defines and symbolizes the city: it made it an island. (...) As in a ship, the wall helped create a feeling of unity between the inhabitants: in a siege or a famine the morality of the shipwreck - share-and-share-alike - developed easily. But the wall also served to build up a fatal sense of insularity: all the more because of the absence of roads and quick means of communication between cities. (...) The street occupied in medieval city planning a quite different place than in an age of locomotion. Except in the country, we inevitably think of houses being built along a line of predetermined streets. But on the less regular medieval sites it would be the other way around: groups of trades or groups of institutional buildings would form self-contained quarters or "islands". Within these "islands", and often outside, as part of the connecting urban tissue, the streets were essentially footways: marks of the daily comings and goings of the inhabitants. "Islands" formed by the castle, the monasteries, or the specialized industrial section of the technically more advanced cities were characteristic features: they had their counterpart in the little internal "islands" one encounters in the Northern countries in the housing foundations for the aged or the poor. The Fuggerei in Augsburg is the most handsomely built survival of this mode (...). (Mumford 1996, 53-56)

Other interventions organize the Senhora das Dores block. Two parallel rows of houses to the west from the fields adjacent to the backside of the Fontainhas's street penetrate into the interior of the block, reproducing the ancient occupation of the ilhas. A diverse group of small buildings, either residential or not, fill up the void spaces, by proposing openings or passages that allow the crossing of the area. A house designed to occupy a void space at the S. Dionísio's street parallel to one of the gables neighbors, interrupts the 
continuity existing in the face of the street and organizes two entrances to the interior of the block.

The row of new houses intersects ruins of old walls preserved as important elements in the organization of the interior of the block. Like a gesture of sympathy towards the another wall, which is perpendicular to the former one and crosses the row of houses at the place their elevation changes, the small walls dividing the houses from one another are designed as fragments broken into two pieces, in order to make compatible, by similarity and through a broken and transitive form (just like at the urbanization of Caxinas), the wall that bears the change of elevation, the longitudinal ruin along Senhora das Dores's street and the new building facing it.

The sash-windows - formerly used at Alcino Cardoso's and Beires's houses - are present again. At the upper floor, a vertical window marks the succession of the houses, whereas at the ground level floor, with wider void spaces, windowpanes with the same design recall once again the traditional architecture of the city.

Remains or fragments of former constructions will also be the starting point, at the south sector, to the completion of three houses, literally superposed, without solution of continuity, to old stonewalls, fragments which physically and formally, support its reconstruction.

Thus, the ruins are a support but not necessarily to mimetic reconstructions. It is 'a gradual approach to town planning so as to supersede criteria of simple restoration or physical elimination of the existing city.' (Siza 1976a, 89)

All this, also with obvious references to the Siedelungen of the twenties, particularly Pieter Oud's work, not only as far as the use of the curved line is concerned (see the residential complex in Hoek van Holland, 1924-27), but also in terms of the rhythms and the articulation of the volumes.

One year after the completion of the first phase of Senhora das Dores's area in Porto, Siza said:
It is an essential problem to be able to link different things, since the present-day city is a complex whole of very different fragments. In a city, the problem lies in making a whole with ruins, buildings of different periods, fragments... (...) In order to develop our methodology it is necessary to try to make a whole out of its parts, which is feasible (...). Now, we recognize the complexity of the city and it is positive that this complexity exists (...). (Siza 1978, 37)

Is not this will to unify - simultaneously recognizing the fragmented condition of the contemporary city - in some way represented by the broken angels which start appearing in many of his sketchbooks? Or else, those ones which - hovering over such projects as in Évora, at the Malagueira residential quarter (1977-), mutilated when flying (title of one of his drawings) - when in contact with the soil are already fragmented, as if stating that the form of the city is no longer possible to represent or build as a whole? 


\section{The Fragmented City}

Up to which extent was this strategy shared by a group of architects interested in the unity of architecture and urbanism? Let us compare this willingness to link the existing and the new with Aldo Rossi's words in the text 'Fragments' published in 1978:

(...) the term "fragments" seems adequate to me to depict the situation of the modern city, the architecture and the society. (...) In its physical meaning (broken things, mutilated elements) or in its general meaning (part of a complete drawing which went lost) there is no doubt that the fragments belong to architecture; and they belong to it almost as constructive elements, almost as theoretical elements. (...) This is perhaps the great dream of the great civil architecture; it is not the harmony in discord, but the beautiful and tidy city thanks to the wealth and variety of its places. This is also why I believe in the future city as the one in which the fragments of something broken in its origin are rearranged (...). (Rossi 1978, 7-8)

Is this not the meaning of the Ora questo è perduto engraving of $1976 ?$

In Aldo Rossi's architecture, we also find deliberately broken or cleaved projects such as the residential quarter of San Rocco in Monza (1966). In the plan for the XIII Triennale, Milan (1963) or at the Piazza del Municipio of Segrate (1965), incomplete architectures are deliberately designed, a reference to archaeological excavation camps (in the pavilion) or to a mutilated or incomplete pre-existence (in Segrate). The displacement of the two parts of S. Rocco surprisingly seems to evoke the cleft designed by the crossing of the Senhora das Dores's street in the residential quarter in Porto.

Beyond all the differences among their work, it is important to underline this moment of convergence. It has been formulated a hypothesis of intervention in the city that refuses the blank slate (tabula rasa), but also its exploitation as consumer goods or its transformation into a thematic park of formal shows without memory.

We must return to the projects of Caxinas e Senhora das Dores to resume the subject of the non-difference between architecture and urbanism. Aldo Rossi has also always defended the same idea, using as an example the city of Spalato, where the Diocletian's Palace is transformed into an urban area, thus showing the permutability and correspondence between architecture and urbanism. 'The city of Spalato represents an extraordinary reference to architects and to those who deal with city and territory. This example denies any distinction between building and city, returns urban values to the womb of architecture and shows that the city itself is architecture in its own right.' (Rossi 1972, 480)

A non difference between architecture and urbanism which can be seen not only in the way monuments transform themselves into urban spaces (cf. also the Arles Amphitheater), but also when the intervention in the city implies 
the consideration of all of its dimensions, from the house to the residential quarter, from the residential quarter to the city. This way of working allows the pinpointing of correspondences among its different scales (and in this regards Siza also stands close to the need, defended by Rossi, to study and project the city by parts).

Projecting the city by parts means accepting the inherent partiality of the proposals, but also the possibility of aiming at the construction, although always incomplete, of a more general or global design that relates them with one another, through the interlinking of the different interventions. With regard to the SAAL process, which includes the intervention at the Senhora das Dores area, Siza notes the need to respond to the dwellers recognition that 'local problems are above all a reflex of the contradictions of the city and the territory in their widest aspects' (Siza 1976b, 101). Let us read again Aldo Rossi: 'I am thinking of a unity, or a system, made solely of reassembled fragments. Perhaps only a great popular movement can give them the sense of an overall design (...).' (Rossi 1981, 18)

At both IBA Berlin competitions (1979-1980), Siza also projects the permeability of the blocks, incorporating existing inner buildings and crossings and, in some cases, proposing others to allow a more diversified and global use of the city.

Buildings and paths, both peripheral and interior, are designed in the continuity of the prevailing ones. In the renewal of one of the blocks of the Fraenkelufer competition, buildings A, B and C occupy the interior, whereas building $\mathrm{D}$, recomposing the perimeter at the corner of streets Fraenkluferstrasse and Admiralstrasse, leads, such as the small building at $\mathrm{S}$. Dionísio's street, to two passages to the interior of the block.

Building B also retrieves the strategy that has already been rehearsed in the Senhora das Dores's area in Porto. With an L-shape, inverted considering what is usual in the city, it opens a new front in the interior of the block with a large curtain wall perforated by openings regularly distributed, having at its center an excavated semi-elliptical negative. The $\mathrm{F}$ building, placed at the corner of Fraenkeluferstrasse and Kholfurterstrasse, with a ruined corner recomposes the perimeter of the block.

\section{Conclusion}

The profound transformation proposed with these projects, both in Berlin and in Porto, paradoxically mean keeping the city simultaneously suspended and resting on its fragmentary condition, open and available to many uses; some of them proposed and designed, others unforeseeable.

In the Temple of Modern Philosophy in Ermenonville (Hubert Robert, ca. 1775) there is an inversion of the ruin as a witness of the passage of time, proposing it, on the contrary, as an unfinished work, purposely incomplete to convey the idea that learning is a never-ending process. It is a manifestation of optimism but also a sign of doubt or uneasiness. Both at S. Victor and at 
Fraenkelufer, or rather still at the swimming pool at Moledo, the invented ruin denotes an empathic relationship with everything that exists, new and ancient, seeking an (im)possible synthesis.

In all these works it is possible to identify a sense of expectation, an anticipatory pause that remits to the civil dimension of the city. It is an open and available architecture. Its goal is the unveiling of the world, of the infinite variety of its correspondences and relations, projected as a work still to become, necessarily incomplete. It imagines the rearrangement of the city from fragments, from remains (or even from clues or traces), from everything sedimented in history and in geography, as this is the only possibility of reading and getting to know the city in all its richness and complexity.

Hence the need to work from the particular to the general, to make different times compatible, unveiling ancient presences, marks or tracks witnessing the history of the city, big grooves through which different times overlap, adapting to each other. This sustains the new, revealing the deep reasons that architecture must be aware of, perhaps at the service of new needs, but starting from the existing and transporting it in some way or another through the project. It is a matter of recognizing the world as it is, but also of recognizing its potentiality that needs to be projected, that is to say, that needs to be identified through imagination.

This work is funded by FEDER Funds through the Operational Program for Competitiveness Factors - COMPETE and National Funds through FCT Foundation for Science and Technology within the project «PEstC/EAT/UI0145/2011».

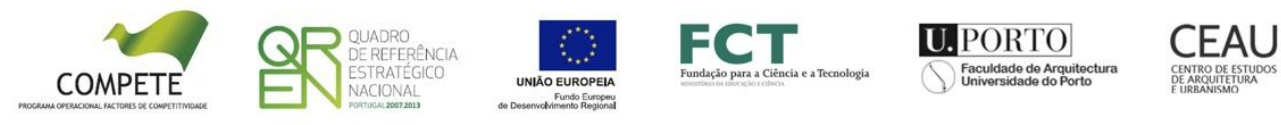

\section{Bibliography}

Mumford, Lewis. 1996. The Culture of Cities. New York: Harcourt Brace \& Company.

Rossi, Aldo. 1972. Architettura e città: passato e presente [Architecture and the city: past and present]. In: Rosaldo Bonicalzi, ed. 2004. Scritti Scelti [Chosen Writings]. Torino: CittàStudiEdizioni. pp. 474-481. [In Italian]

Rossi, Aldo. 1978. Frammenti [Fragments]. In: A. Ferlanga, Aldo Rossi, architetture 1959-1987 [Aldo Rossi, architetture 1959-1987]. Milano: Electa. pp. 7-8. [In Italian]

Rossi, Aldo. 1981. Autobiografía científica [A Scientific Autobiography]. Barcelona: Gustavo Gili. [In Spanish]

Siza, Álvaro. 1976a. L'isola proletaria come elemento base del tessuto urbano [The proletarian island as the basic element of the urban tissue]. Lotus International $\mathrm{nr}$. 13, 1976. Milano: Electa. pp. 80-93. [In Italian] 
Siza, Álvaro. 1976b. Tres Intervenciones en la Ciudad de Oporto [Three interventions in the city of Porto]. In: S. Tarragò, J. G. Beramendi, ed. Proyecto y ciudad histórica, I Seminario Internacional de Arquitectura en Compostela [Architectural project and the historical city, I International Seminar of Architecture in Compostela]. Colexio Oficial de Arquitectos de Galicia. p. 85101. [In Spanish]

Siza, Álvaro. 1978. Entretien avec Álvaro Siza [Interview with Álvaro Siza]. AMC nr. 44, Feb. 1978, pp. 33-41. [In French]

Siza, Álvaro. 1979. Casa Alcino Cardoso [Alcino Cardoso house]. In: A. Cianchetta, E. Molteni, ed. 2004. Álvaro Siza, casas 1954-2004 [Álvaro Siza, houses 19542004]. Barcelona: Gustavo Gili. p. 72. [In Spanish]

Siza, Álvaro. 1996. Je ne fais pas de distinction entre architecture et urbanisme [I don't make any distinction between architecture and urbanism]. In: D. Machabert, L Beaudoin, ed. 2008. Álvaro Siza, Une question de mesure, entretiens avec Dominique Machabert et Laurent Beaudoin [Álvaro Siza, A question of measure, interviews with Dominique Machabert and Laurent Beaudoin] Éditions Le Moniteur. pp. 163-174. [In French] 